\title{
Effects of Nutrient Sources and Transplanting Age on the Growth and Yield of Sorghum (Sorghum Bicolor L. Moench) in Bauchi State, Nigeria
}

\author{
Shuaibu YM*, Kawure S, Bala RA, Sabo MU and Nayaya JA \\ Department of Crop Production, Faculty of Agriculture and Agricultural Technology, Abubakar Tafawa \\ Balewa University, Bauchi, Nigeria
}

\begin{abstract}
A field experiment was conducted to study the effects of nutrient sources and transplanting age on the growth and yield of sorghum (Sorghum bicolor (L.) Moench) at teaching and research farm of Bauchi State College of Agriculture $\left(10^{\circ} 22^{\prime} \mathrm{N}\right.$ and $9^{\circ} 47^{\prime} \mathrm{E}$ ), during the rainy season of 2020 . The treatment consisted of three nutrient sources (poultry manure, chicken feather and inorganic fertilizer), a control and three transplanting ages (0,2 and 3 weeks old). These were factorially combined to give 12 treatments combination and laid out in a randomized complete block design (RCBD) with three replications. Growth data were collected at two weeks interval on plant height, number of leaves and leaf area. Yield data were collected at harvest on panicle length, 1000 grain weight and grain yield. All data collected were subjected to analysis of variance (ANOVA) and Duncan's Multiple Range Test (DMRT) was adopted in separating the means. The result of the experiment revealed a significant $(P \leq 0.05)$ difference among the treatments used. The result further indicated that, inorganic fertilizer (NPK) was proved to be statistically $(P \leq 0.05)$ better than the other nutrient sources used in all the parameters observed. Transplanting age on the other hand, the result showed that direct sowing and transplanting at 3 weeks old performed significantly $(P \leq 0.05)$ better in terms of growth and yield of sorghum. Based on the findings of this study, application of NPK fertilizer at the rate of $60 \mathrm{~kg} \mathrm{~N}, 30 \mathrm{~kg} \mathrm{P}$ and K/ha to direct seeded or transplanted sorghum at the age of 3 WO proved to be better than the other treatments and can be used by farmers in the study area for sustainable sorghum production.
\end{abstract}

\section{Keywords}

Sorghum, Chicken feather, Poultry manure, Transplanting, Age

\section{Introduction}

Sorghum (sorghum bicolor L.) belonging to the family poaceae is an important annual cereal crop grown for both grain and palatable green forage production. It is the fifth most important cereal crops in the world after wheat, maize, rice and barley interns of importance and production [1]. The crop provides staple food for many countries of the world including Nigeria. Its tolerance to drought and superior adaptation to marginal environments makes it an attractive crop in rain fed production system [2]. In spite of the increase in land areas under sorghum production, yield is still low in subsaharan Africa. One of the major causes of low yield is declining soil fertility resulting in severe nutrient depletion of soils [3].

Sorghum requires an adequate supply of nutrients particularly Nitrogen, Phosphorus and Potassium for good growth and higher yield. Although there is reasonable development as to yield in sorghum as a result of NPK and Urea fertilizers, it is necessary to ensure the proper use of manure and other organic materials in the cultivation of sorghum as the sole use of inorganic fertilizers leads to solemn depletion of soil materials [4]. Intensification of agricultural system has resulted in declining nutrient availability, soil acidification, compaction and build-up of pest and diseases leading to decline in crop yield. Low soil fertility, poor stand establishment and lack of knowledge of the right quantity of organic and inorganic fertilizer have so far been the major reasons for the decline in production and effective growth of sorghum.

*Corresponding author: Shuaibu YM, Department of Crop Production, Faculty of Agriculture and Agricultural Technology, Abubakar Tafawa Balewa University, Bauchi, Nigeria

Accepted: December 29, 2021

Published online: December 31, 2021

Citation: Shuaibu YM, Kawure S, Bala RA, et al. (2021) Effects of Nutrient Sources and Transplanting Age on the Growth and Yield of Sorghum (Sorghum Bicolor L. Moench) in Bauchi State, Nigeria. Arch Crop Sci 4(1):99-105 
Citation: Shuaibu YM, Kawure S, Bala RA, et al. (2021) Effects of Nutrient Sources and Transplanting Age on the Growth and Yield of Sorghum (Sorghum Bicolor L. Moench) in Bauchi State, Nigeria. Arch Crop Sci 4(1):99-105

Poultry manure application improves the physical properties of the soil. It significantly decreases bulk density and increases total porosity, infiltration capacity and water holding capacity. Soil physical properties such as bulk density, water holding capacity and percentage water stable aggregation were noted to be favouarbly influenced by poultry waste addition to soil [5]. Mbagwu [6] reported that poultry manure significantly decreased bulk density and increased infiltration capacity and available water capacity. Amanullah et al. [7] revealed that poultry litter contains a considerable amount of organic matter due to the manure and the bedding material. Litter can also have an impact on soil $\mathrm{pH}$ and liming due to varying amounts of calcium carbonate in poultry feed. Poultry manure improved soil physical properties significantly by reducing soil bulk density and temperature and increasing total porosity and moisture content in Nigeria [8].

Feather meal is a by-product of the turkey and poultry processing industry. Chicken feathers are keratin-rich waste generated in large amounts from poultry processing industries. High mechanical stability and rigid nature of keratin make them resistant to degradation by common proteolytic enzymes present in nature [9]. Preparation of bio fertilizers using chicken feather wastes is attracting the focus of many research scientists. Feather meal is a cheap and easily available source of nitrogen $(15 \% \mathrm{~N})$ and may serve as a potential bio fertilizer [10]. It is a slow releasing fertilizer providing plants with nitrogen over an extended period of time, making it perfect for plants like corn and leaf vegetables requiring a consistent supply of nitrogen [9]. Once the feather meal begins to release its nitrogen, which is normally within 4-7 days of application, it will release at a steady rate for approximately 3 months where more than 75 percent of all the nitrogen will be utilized by the plant [11]. This experiment was therefore carried out to study the best among the different nutrient sources (organic and inorganic fertilizers) and best age of transplanting on the growth and yield of sorghum in the study area.

\section{Materials and Methods}

The experiment was conducted to study the effects of nutrient sources and transplanting age on the growth and yield of sorghum (Sorghum bicolor (L.) Moench) at teaching and research farm of Bauchi State College of Agriculture $\left(10^{\circ} 22^{\prime} \mathrm{N}\right.$ and $\left.9^{\circ} 47^{\prime} \mathrm{E}\right)$, during the rainy season of 2020 . The materilas for the experiment are; sorghum variety (SK5912) which was obtained from the seed multiplication unit of Bauchi state agricultural development programme (BSADP), poultry manure and chicken feather obtained from Mudalawal market and inorganic fertilizer (NPK) which was also obtained from BSADP.

The treatment consisted of three nutrient sources (poultry manure, chicken feather and inorganic fertilizer), a control and three transplanting ages (0, 2 and 3 weeks old). These were factorially combined to give 12 treatments combination and laid out in a randomized complete block design (RCBD) with three replications. A plot size of $16 \mathrm{~m}^{2}$ was adopted for the experiment, $0.5 \mathrm{~m}$ was used as a boarder row between plots and $1 \mathrm{~m}$ was left as a walk way between the replications. The plot was ploughed and harrowed before laying out of the experiment. The organic fertilizers (poultry litter and row chicken feather) were applied at the rate of 2 ton/ha and incorporated into the soil 2 weeks before planting. The inorganic fertilizer was applied at the rate of $60 \mathrm{~kg} / \mathrm{ha}(\mathrm{N}), 30$ $\mathrm{kg} \mathrm{k} / \mathrm{ha}\left(\mathrm{P}_{2} \mathrm{O}_{2}\right)$ and $30 \mathrm{~kg} / \mathrm{ha}\left(\mathrm{K}_{2} \mathrm{O}\right)$ in two split dosses. The first doss (basal) was applied in form of NPK 15:15:15 at the rate of $30 \mathrm{~kg} /$ ha 1 week after planting, while the remaining $30 \mathrm{~kg}$ $\mathrm{N} /$ ha (top dress) was applied in form or Urea (46\% N) 5weeks after planting.

The nursery site was first cleared of weeds, worked in properly and a bed raised before sorghum seeds were broadcasted which were later covered lightly with soil. Direct seeded plots were sown at a spacing of $25 \mathrm{~cm} \times 75$ $\mathrm{cm}$ intra and inter row respectively. Five to seven seeds were sown which were later thinned to two seeding per stand at two weeks after sowing (WAS). A ball of earth method of transplanting was used to transplant the seedlings from the nursery to the main field. Seedlings were transplanted at $2 \mathrm{WO}$ and $3 \mathrm{WO}$ at a spacing of $25 \mathrm{~cm} \times 75 \mathrm{~cm}$ intra and inter row with two seedlings per stand. Before sowing and transplanting a systemic, non-selective herbicide mixed with powder (Glyphosate and Atrazin powder) was applied to control the growth and prevent the germination of new weeds. However, manual weeding was carried out at 6 weeks after sowing using a hand hoe. The crop was harvested by first cutting down the entire plant at maturity after which the panicles were removed using knife manually and left to dry under the sun for a week. The dried panicles were then threshed manually with stick and winnowed to remove the chaff. Growth data were collected from ten (10) randomly targeted plants from the net plot at two weeks interval on plant height, number of leaves and leaf area. Yield data were collected at harvest on panicle length, 1000 grain weight and grain yield. All data collected were subjected to analysis of variance (ANOVA) and Duncan's Multiple Range Test (DMRT) was adopted in separating the means.

\section{Result and Discussion}

\section{Plant height}

Effect of transplanting age and nutrient sources on plant height of sorghum is presented in (Table 1 ). The result revealed a significant $(P \leq 0.05)$ difference among the various treatments used throughout the study period. The result further showed that, application of inorganic fertilizer significantly $(P \leq 0.05)$ produced taller plants than all other treatments considered, but all treatments were better than the control. Transplanting age on the other hand, the result indicated that, direct seeded sorghum significantly $(P \leq 0.05)$ produced taller plants than when transplanted. However, seedlings transplanted at 2 and 3 WO were observed to be at far in terms of plant height. The significant $(P \leq 0.05)$ difference observed throughout the study period on plant height indicated that, taller plants can be obtained through application of inorganic fertilizer and direct seeding of sorghum. It further revealed the importance of direct seeding on plant height of sorghum. The result of this findings is in line with the findings of Ismaeil, et al. [12], 
Citation: Shuaibu YM, Kawure S, Bala RA, et al. (2021) Effects of Nutrient Sources and Transplanting Age on the Growth and Yield of Sorghum (Sorghum Bicolor L. Moench) in Bauchi State, Nigeria. Arch Crop Sci 4(1):99-105

Table 1: Effect of transplanting age and nutrient sources on plant height $(\mathrm{cm})$ of sorghum.

\begin{tabular}{|c|c|c|c|c|}
\hline \multicolumn{5}{|l|}{ WAS } \\
\hline Treatment & 4 & 6 & 8 & 10 \\
\hline \multicolumn{5}{|l|}{ Nutrient Sources } \\
\hline Control & $32.32^{c}$ & $61.47^{c}$ & $52.22^{c}$ & $60.56^{c}$ \\
\hline Inorganic Fertilizer & $65.67^{\mathrm{a}}$ & $118.26^{\mathrm{a}}$ & $177.55^{\mathrm{a}}$ & $239.67^{a}$ \\
\hline Poultry Manure & $65.67^{\mathrm{b}}$ & $97.00^{b}$ & $130.68^{b}$ & $169.58^{b}$ \\
\hline Chicken Feathers & $62.33^{b}$ & $97.31^{b}$ & $127.00^{b}$ & $162.50^{c}$ \\
\hline LS & ${ }^{* *}$ & ${ }^{* *}$ & $* *$ & ${ }^{* *}$ \\
\hline $\mathrm{SE} \pm$ & 1.86 & 1.86 & 8.57 & 8.30 \\
\hline \multicolumn{5}{|l|}{ Transplanting Age } \\
\hline DS & $64.41^{\mathrm{a}}$ & $112.02^{\mathrm{a}}$ & $139.98^{\mathrm{a}}$ & $171.47^{\mathrm{a}}$ \\
\hline $2 \mathrm{WO}$ & $43.08^{b}$ & $58.28^{\mathrm{b}}$ & $87.93^{b}$ & $132.19^{b}$ \\
\hline 3 Wo & $47.50^{\mathrm{b}}$ & $67.23^{b}$ & $94.70^{b}$ & $140.57^{b}$ \\
\hline LS & ${ }^{* *}$ & $* *$ & ${ }^{* *}$ & ${ }^{* *}$ \\
\hline SE \pm & 1.61 & 5.71 & 7.42 & 7.19 \\
\hline \multicolumn{5}{|l|}{ Interaction } \\
\hline $\mathrm{NS} \times \mathrm{TA}$ & NS & NS & NS & NS \\
\hline
\end{tabular}

Means followed by the same letter within the same column are not statistically different following DMRT.

WAS = Weeks After Sowing; WO = Weeks Old; DS = Direct Sowing; LS = Level of Significance; SE = Standard Error; ${ }^{* *}=$ Significant at $0.01 ;$ NS $=$ Not Significant

who reported a significant effect of inorganic fertilizer on growth of sorghum. The increase in plant height could be as a result of lack of stress and exposure to certain hardening condition on sorghum at seedling stage.

This is in line with an earlier report of Adesanwo, et al. [13] who reported that transplanting of seedlings reduces their growth and development, and that in general, the extent of injury or reduction in growth is more or less directly proportional to the severity and duration of the water deficit within the plant tissue. The taller plants as observed under the application of poultry manure and chicken feather indicated a better mineralization of the poultry products and could be due to lower carbon to nitrogen ratio. The result of this findings is in line with the report of Amanullah et al. [7] who reported that, increase in plant height as a result of poultry manure application could be due to higher availability of soil nutrients and its uptake by the plant.

\section{Number of leaves}

Effect of transplanting age and nutrient sources on the number of leaves of sorghum is presented in (Table 2). The result in table 2 revealed a significant $(P \leq 0.05)$ difference among the various treatments used throughout the study period. The result further indicated that, except at 6 and 10 WAS, where no significant $(P \leq 0.05)$ difference was observed, application of inorganic fertilizer significantly $(P \leq 0.05)$ gave higher number of leaves than the other treatments considered. Study on transplanting age revealed that, direct seeded sorghum and transplanting at 3 WO significantly $(P \leq$ $0.05)$ gave higher number of leaves than when transplanted at 2 WO. The significant $(P \leq 0.05)$ difference observed throughout the study period on number of leaves in which application of inorganic fertilizer and direct seeded sorghum and transplanting at 3 WO proved to produce higher number of leaves than all other treatment indicated that higher number of leaves can be obtained through application of inorganic fertilizer and direct seeding of sorghum. This confirm the result of Belete et al. [14] who reported that inorganic fertilizer application levels has a significant contribution on vegetative growth of plants. The application of poultry manure and chicken feathers was observed to produce statistically similar number of leaves with mineral fertilizer. This revealed the potentials of the two poultry products in supplementing or replacing inorganic fertilizer in sorghum production. Agbede et al. [8] reported similar result that, application of poultry litter supplies nutrients necessary for crop growth and the most prevalent being nitrogen and also has the potential for competing with inorganic fertilizers. The better performance observed in this study as a result of addition of the different nutrient sources could also be due to increase in organic matter content of the soil. The results also conforms with the report of Montemurro et al. [15] that, the quantity of organic matter in the soil depends directly on the amounts of organic material introduced to the soil either by natural return through roots, stubbles and root exudates or by artificial application in the form of organic manure.

\section{Leaf area $(\mathrm{cm})$}

Effect of transplanting age and nutrient sources on leaf area of sorghum is represented in (Table 3 ). The result revealed a significant $(P \leq 0.05)$ difference among various treatments used throughout the study period. The result also showed that, except at 6WAS where no significant $(P \leq 0.05)$ difference was observed, application of inorganic fertilizer and poultry manure significantly $(P \leq 0.05)$ gave higher leaf area than the other treatments and all the treatments were better than control. Transplanting age on the other hand, the result indicated that direct seeded sorghum and transplanting at 3WO gave statistically $(P \leq 0.05)$ higher leaf area throughout the study period. The increase in leaf area as observed with the application of inorganic fertilizer and poultry manure could be due to quick release and availability of nutrient in 
Citation: Shuaibu YM, Kawure S, Bala RA, et al. (2021) Effects of Nutrient Sources and Transplanting Age on the Growth and Yield of Sorghum (Sorghum Bicolor L. Moench) in Bauchi State, Nigeria. Arch Crop Sci 4(1):99-105

Table 2: Effect of transplanting age and nutrient sources on the number of leaves of sorghum.

\begin{tabular}{|c|c|c|c|c|}
\hline \multicolumn{5}{|l|}{ WAS } \\
\hline Treatment & 4 & 6 & 8 & 10 \\
\hline \multicolumn{5}{|l|}{ Nutrient Sources } \\
\hline Control & $3.72^{c}$ & 9.00 & $9.68^{b}$ & 10.44 \\
\hline Inorganic Fertilizer & $9.67^{a}$ & 8.67 & $10.78^{\mathrm{a}}$ & 10.89 \\
\hline Poultry Manure & $6.33^{b}$ & 9.78 & $10.78^{\mathrm{a}}$ & 11.78 \\
\hline Chicken Feathers & $5.77^{b}$ & 9.78 & $10.67^{a}$ & 11.44 \\
\hline LS & ${ }^{* *}$ & NS & $*$ & NS \\
\hline SE \pm & 0.25 & 0.47 & 0.31 & 0.58 \\
\hline \multicolumn{5}{|l|}{ Transplanting Age } \\
\hline DS & $7.25^{\mathrm{a}}$ & $10.58^{a}$ & $11.42^{\mathrm{a}}$ & $12.25^{\mathrm{a}}$ \\
\hline $2 \mathrm{WO}$ & $5.17 b$ & $8.08^{b}$ & $9.08^{b}$ & $9.33^{b}$ \\
\hline $3 W 0$ & $6.71^{\mathrm{a}}$ & $10.23^{\mathrm{a}}$ & $10.92^{\mathrm{a}}$ & $11.83^{\mathrm{a}}$ \\
\hline LS & $* *$ & $* *$ & $* *$ & $* *$ \\
\hline SE \pm & 0.22 & 0.41 & 0.27 & 0.49 \\
\hline \multicolumn{5}{|l|}{ Interaction } \\
\hline NS $\times T A$ & NS & NS & NS & NS \\
\hline
\end{tabular}

Means followed by the same letter within the same column are not statistically different following DMRT.

WAS = Weeks After Sowing; WO = Weeks Old; DS = Direct Sowing; LS = Level of Significance; SE = Standard Error; ${ }^{* *}=$ Significant at $0.01,{ }^{*}=$ Significant at 0.05; NS = Not Significant

Table 3: Effect of transplanting age and nutrient sources on leaf area $(\mathrm{cm})$ of sorghum.

\begin{tabular}{|c|c|c|c|c|}
\hline \multicolumn{5}{|l|}{ WAS } \\
\hline Treatment & 4 & 6 & 8 & 10 \\
\hline \multicolumn{5}{|l|}{ Nutrient Sources } \\
\hline Control & $61.78^{c}$ & 302.12 & $251.69^{b}$ & $315.14^{b}$ \\
\hline Inorganic Fertilizer & $162.78^{a}$ & 319.46 & $304.24^{\mathrm{ab}}$ & $389.67^{b}$ \\
\hline Poultry Manure & $153.22^{\mathrm{ab}}$ & 329.53 & $334.07^{a}$ & $424.88^{a}$ \\
\hline Chicken Feathers & $141.67^{b}$ & 307.81 & $337.17^{\mathrm{a}}$ & $384.74^{\mathrm{a}}$ \\
\hline LS & ${ }^{* *}$ & NS & ${ }^{*}$ & ${ }^{* *}$ \\
\hline $\mathrm{SE} \pm$ & 4.40 & 24.86 & 20.14 & 17.17 \\
\hline \multicolumn{5}{|l|}{ Transplanting Age } \\
\hline DS & $169.42^{\mathrm{a}}$ & $363.33^{\mathrm{a}}$ & $352.91^{\mathrm{a}}$ & $406.12^{\mathrm{a}}$ \\
\hline $2 \mathrm{WO}$ & $61.42^{\mathrm{b}}$ & $245.85^{b}$ & $217.31^{b}$ & $315.95^{b}$ \\
\hline $3 W O$ & $158.70^{\mathrm{a}}$ & $335.02^{\mathrm{a}}$ & $350.15^{a}$ & $413.78^{a}$ \\
\hline LS & ** & $* *$ & $* *$ & ${ }^{* *}$ \\
\hline $\mathrm{SE} \pm$ & 3.81 & 21.53 & 17.44 & 14.87 \\
\hline \multicolumn{5}{|l|}{ Interaction } \\
\hline NS $\times$ TA & NS & NS & NS & NS \\
\hline
\end{tabular}

Means followed by the same letter within the same column are not statistically different following DMRT.

WAS $=$ Weeks after Sowing; WO = Weeks old; DS = Direct Sowing; LS = Level of Significance; SE $=$ Standard Error; ${ }^{* *}=$ Significant at 0.01 ; $*$ = Significant at $0.05 ; \mathrm{NS}=$ Not Significant

the soil as poultry manure is known to have lower carbonnitrogen ratio. The result of this study is in agreement with the findings of Shuaibu et al. [16] that organic manure results in improved growth and yield of sorghum.

The significant difference observed on transplanting age indicates that, higher leaf area can be obtained through direct seeding and transplanting at 3 WO. The present report lend support from the work of Baudron et al. [17] who reported that transplanting of plants destroy some parts, if not all, of the region of the plant absorption. Higher leaf area produced by direct seeded sorghum could also be due to the zero exposure and disturbance of the plant region of absorption which help mainly in photosynthesis as against the transplanted seedlings. The higher leaf area observed under poultry manure and chicken feather could be as a result of its improvement of the soils physical characteristics such as decrease in bulk density, increase in total porosity, infiltration and water holding capacity. The results of this finding is in conformity with an earlier one by Mbagwu et al. [6] that, poultry manure significantly decreases bulk density, increases total porosity, infiltration capacity and availability of water in the soil. It could also be as a result of slow release of plant nutrients by the poultry manure and chicken feather making the nutrients available to the plant for an extended period of time. This is in line with the report of Lateef et al. [9] who reported that, chicken feather is a slow release fertilizer, providing plants with nitrogen over an extended period of time. 
Citation: Shuaibu YM, Kawure S, Bala RA, et al. (2021) Effects of Nutrient Sources and Transplanting Age on the Growth and Yield of Sorghum (Sorghum Bicolor L. Moench) in Bauchi State, Nigeria. Arch Crop Sci 4(1):99-105

Table 4: Effect of transplanting age and nutrient sources on panicle length, 1000 grain weight and grain yield of sorghum.

\begin{tabular}{|c|c|c|c|}
\hline \multirow[b]{2}{*}{ Treatment } & \multicolumn{3}{|c|}{ Parameters } \\
\hline & Panicle length & 1000 grain weight & Grain Yield (Kg/ha) \\
\hline Nutrient Sources & $23.69^{c}$ & $20.37^{c}$ & $1495.14^{c}$ \\
\hline Control & $28.83^{a}$ & $21.56^{a}$ & $3411.26^{\mathrm{a}}$ \\
\hline Inorganic Fertilizer & $26.58^{b}$ & $20.13^{b}$ & $2565.89^{b}$ \\
\hline Poultry Manure & $25.46^{b c}$ & $20.92^{b}$ & $2412.87^{b}$ \\
\hline \multicolumn{4}{|l|}{ Chicken Feathers } \\
\hline LS & ** & $* *$ & ** \\
\hline $\mathrm{SE} \pm$ & 0.63 & 0.22 & 151.59 \\
\hline \multicolumn{4}{|l|}{ Transplanting Age } \\
\hline DS & $30.67^{a}$ & $20.23^{b}$ & $2591.97^{b}$ \\
\hline $2 \mathrm{WO}$ & $20.50^{\mathrm{b}}$ & $20.17^{b}$ & $2432.22^{\mathrm{b}}$ \\
\hline 3 Wo & $22.58^{b}$ & $21.58^{a}$ & $3214.68^{a}$ \\
\hline LS & ${ }^{* *}$ & ${ }^{* *}$ & ${ }^{* *}$ \\
\hline$S E \pm$ & 0.94 & 0.19 & 131.28 \\
\hline \multicolumn{4}{|l|}{ Interaction } \\
\hline NSXTA & NS & NS & NS \\
\hline
\end{tabular}

Means followed by the same letter within the same column are not statistically different following DMRT. WAS = Weeks after Sowing; WO = Weeks Old; DS = Direct Sowing; LS = Level of Significance; SE = Standard Error; ${ }^{* *}=$ Significant at 0.01; NS = Not Significant

\section{Panicle length}

Effect of transplanting age and nutrient sources on panicle length of sorghum is represented in (Table 4). The result showed that, application of inorganic fertilizer significantly $(P \leq 0.05)$ gave higher panicle length than the other treatments used. However, all treatments were better than the control throughout the study period. Transplanting age on the other hand, the result revealed that transplanting at 3WO significantly $(P \leq 0.05)$ gave bigger panicle than direct seeding and when transplanted at $2 \mathrm{WO}$. The bigger panicles as observed with the application of inorganic fertilizer revealed the importance of $\mathrm{N}$ as a basic component of plant physiological activities as reported by Fagam, et al. [18] working on nitrogen fertilizer in cereal production. The higher performance of sorghum transplanted at $3 \mathrm{WO}$ indicated the importance of transplanting older seedlings in sorghum production. The result of this study contradict the findings of Baudron et al. [17] who reported that transplanting of plants destroy some parts, if not all, of the region of the plant absorption. The better performance of sorghum as observed with application of plant nutrient over control could be due their impact on soil properties, nitrogen availability and uptake in the soil. The result of this findings lend support from the report of Weber et al. [19] poultry manure and chicken feather had a significant effect on soil properties, nutrient availability and their uptake by plant.

\section{0 grain weight $(\mathrm{g})$}

Effect of transplanting age and nutrient sources on 1000 grain weight $(\mathrm{g})$ of sorghum is also presented in (Table 4). The result in table 4 revealed a significant $(P \leq 0.05)$ among the treatments used on grain weight of sorghum. The result further showed that, application of inorganic fertilizer significantly $(P \leq 0.05)$ gave heavier grains of sorghum than other treatments throughout the study period but all the treatments were better than the control. Transplanting age on the other hand, the result revealed that transplanting at $3 \mathrm{WO}$ significantly $(P \leq 0.05)$ gave heavier grains than direct seeding and when seedlings are transplanted at $2 \mathrm{WO}$. This result is in line with the report of Adesanwo, et al. [13] who reported an increase in grain weight of transplanted cereal with increase in seedling age since transplanted crop plant prove resistance to pests, diseases and are stronger than direct seeded plant. The heavier grains as observed throughout the study period with various nutrient sources indicated the importance of fertilization to the yield of sorghum.

Sorghum plant shows a differential response to various organic sources used. This could be as a result of their various contribution to fertility status of the soil. This corroborate the report of Kuncoro et al. [5] who reaffirmed that, organic additives reduce the compactness of soil by improving soil aeration and water penetration. The heavier grians observed under poultry manure and chicken feathers could be attributed to their low carbon to nitrogen ratio, their ability to increase the exchangeable basis in the soil and making the nutrient available for better uptake by the plant. This is in conformity with the findings of Agbede et al. [8] that, poultry products have an impact on soil $\mathrm{pH}$ and liming due to varying amounts of calcium carbonate and improve soil physical properties by reducing bulk density, temperature and increasing total porosity and moisture content.

\section{Grain yield (kg/ha)}

Table 4 presented the result on the effect of transplanting age and nutrient sources on grain yield $(\mathrm{kg} / \mathrm{ha})$ of sorghum. The result revealed a significant $(P \leq 0.05)$ difference among the various treatments considered. The result further indicated that, application of inorganic Fertilizer significantly $(P \leq 0.05)$ gave higher grain yield than other treatments and all the treatments were better than the control. Transplanting age on the other hand, it was observed that transplanting at 3 WO significantly $(P \leq 0.05)$ produced higher grain yield than direct seeding and when the seedlings are transplanted at $2 \mathrm{WO}$. The increase in yield with the application of inorganic 
Citation: Shuaibu YM, Kawure S, Bala RA, et al. (2021) Effects of Nutrient Sources and Transplanting Age on the Growth and Yield of Sorghum (Sorghum Bicolor L. Moench) in Bauchi State, Nigeria. Arch Crop Sci 4(1):99-105

fertilizer as observed in this study indicates the effects of inorganic fertilizer in production of sorghum.

The result of this findings lend supports from the findings of Kagwiria et al. [20] who reported that higher application of manure in combination with inorganic fertilizer will positively affect soil fertility in sorghum production. The increase in yield with increase in transplanting age could be due to exposure to harsh condition leading to hardening and resistant to environmental stress. The result obtained is in conformity with the report of Habyrimana et al. [21] who reported that yield of transplanted plants increases due to exposure to harden conditions which tend to make the plants stronger and resistant to pest and diseases. This enables the plants to perform better than the direct seeded plants. The higher grain yield as observed with the application of nutrient sources revealed the impact of fertilization in sorghum production. This corroborate the report of Silva et al. $[22,23]$ who observed an increase in castor seed yield due to application of nitrogen rich fertilizers.

The increase in yield as observed in this study in which the application of poultry manure, chicken feather and mineral fertilizer yielded higher indicated the importance of these fertilizers to soil fertility. The increase in grain yield with the application of poultry products could be due their lower carbon to nitrogen ratio, could also be attributed to increase in soil organic carbon and improvement in soil physical properties. This is in line with the report of Agbede et al. [8] that, poultry products have an impact on soil $\mathrm{pH}$ and liming due to varying amounts of calcium carbonate and improves soil physical properties by reducing bulk density, temperature and increasing total porosity and moisture content. The result of this findings also lend support from the report of Kuncoro et al. [5] who reaffirmed that, organic additives reduce the compactness of soil by improving soil aeration and water penetration.

\section{Conclusion and Recommendation}

In conclusion however, inorganic fertilizer application and transplanting of sorghum had a significant effect on growth and yield of sorghum. Based on the result of this findings, application of NPK fertilizer at the rate of $60: 30: 30 \mathrm{~kg} / \mathrm{ha}$ to direct seeded or sorghum transplanted at three weeks old can be used for increased productivity of sorghum in the study area. Further research with higher rates of organic fertilizers used in this research and more weeks before transplanting is recommended to exploit more inference in the study area.

\section{Conflict of Interest Declaration}

The authors of this article declared that there is no conflict of interest.

\section{References}

1. Kaushal K, Kaushik MK, Vinod KY, et al. (2017) Effects of fertility level on yield and yield attributes of different sorghum [Sorghum bicolar (L.) Moench] genotype. J Pharmacogn Phytochem 6: 541-543.

2. Musa EM, Elsheik EF, Mohammed IA, et al. (2011) Intercropping sorghum and cowpea: Effect of bradyrhizobium inoculation and fertilization on mineral composition of cowpea seeds. Int J Agric Res 1: 138-146.
3. Bationo A, Ntare BR, Tarawali S, et al. (2010) Soil fertility management and cowpea production in the Semi-Arid tropics of West Africa. Afr Crop Sci J 18: 242-248.

4. Shuaibu YM, Garba AA, Voncir N (2015) Influence of legume residue and nitrogen fertilizer on the growth and yield of sorghum (Sorghum bicolor (I.) Moench) in Bauchi State, Nigeria. African J Food Agric Nutr 15: 10060-10076.

5. Kincora PH, Koga K, Satta N, et al. (2014) A study on the effect of compaction on transport properties of soil gas and water I: Relative gas diffusivity, air permeability, and saturated hydraulic conductivity. Soil Tillage Res 143: 172-179.

6. Mbagwu JSC (1992) Improving the productivity of a degraded ultisol in Nigeria using organic and inorganic amendments. Part 2. Changes in physical properties. Bioresour Technol 42: 167-175.

7. Amanullah MM, Somasundaram E, Vaiyapuri K, et al. (2007) Poultry manure to crops: A review. Agric Rev 28: 216-222.

8. Agbede TM, Ojeniyi SO, Adeyemo AJ (2008) Effect of poultry manure on soil physical and chemical properties, growth and grain yield of sorghum in southwest, Nigeria. Am Eurasian J Sustain Agric 2: 72-77.

9. Lateef A, Oloke JK, Gueguim EB, et al. (2010) Keratinolytic activities of a new feather- degrading isolate of Bacillus cereus LAU 08 isolated from Nigerian soil. Int Biodeterior 64: 162-165.

10. Jeong JH, Lee OM, Jeon YD, et al. (2010a) Production of keratinolytic enzyme by a newly isolated feather-degrading Stenotrophomonas maltophilia that produces plant growthpromoting activity. Process Biochem 45: 1738-1745.

11. Das R, Tiwary BN (2014) Production of indole acetic acid by novel bacterial strain of planomicrobium chinense isolated from diesel oil contaminated site and its impact on the growth of vigna radiate. Eur J Soil Biol 62: 92-100.

12. Ismaeil A, Abusuwar A, Ahmed E (2012) Influence of chicken manure on growth and yield of forage sorghum (Sorghum bicolor L. Moench). Int J Agriculture and Forestry 2: 56-60.

13. Adesanwo OO, Adtunji MT, Adesanwo JK, et al. (2016) Evalution of traditional practice for sorghum cultivation in south Western Nigeria. AEJA 2: 45-49.

14. Belete K, Sarmiso Z (2015) Effect of nitrogen fertilizer on Striga infestation, yield and yield related traits of sorghum varieties at Kile, eastern Ethiopia. Biol Agric Hortic 24: 293-300.

15. Montemurro F, MaioranaM, Convertini G, et al. (2006) Compost organic amendments in fodder crops: Effects on yield, nitrogen utilization and soil characteristics. Compost Sci Util 14: 114-123.

16. Shuaibu YM, Fagam AS, Kawure S (2018) Effects of poultry manure based compost and NPK fertilizer on the growth and yield of sorghum (Sorghum bicolor (L.) Moench) in Bauchi state Nigeria. GSC Biol Pharm Sci 2: 16-24.

17. Baudron F, Jaleta M, Okitoi $O$, et al. (2014). Conservation agriculture in african mixed crop-livestock systems: Expanding the niche. Agric Ecosyst Environ 187: 171-182.

18. Fagam AS, Buba U, Yahaya IM, et al. (2009) Effect of variety and nitrogen Level on growth, yield and yield component of maize (Zea mays L.) in Bauchi Nigeria. Proceedings of $23^{\text {rd }}$ annual national conference of farm management association of Nigeria.

19. Weber J, Kocowicz A, Bekier J, et al. (2014) The effect of a sandy soil amendment with municipal solid waste (MSW) compost on nitrogen uptake efficiency by plants. Eur J Agron 54: 54-60. 
20. Kagwiria D, Koech OK, Kinama JM, et al. (2019) Sorghum production practices in an integrated crop-livestock production system in Makueni county, eastern Kenya. Trop Subtrop Agroecosystems 22: 13-23.

21. Habyarimana E, Lorenzoni C, Redaelli R, et al. (2018) Towards a perennial biomass sorghum crop: A comparative investigation on biomass yield and overwintering of sorghum bicolor $\times \mathrm{S}$. halepense lines relative to long term S. bicolor trials in northern Italy. Biomass and bioenergy 111: 187-195.
22. Silva TRB, Leite VE, Silva ARB, et al. (2007) Nitrogen sidedressing fertilization on castor plant in no tillage system. Pesqi Agropecu Bras 42: 1357-1359.

23. FAO (2011) Current world fertilizer trends and outlook to 2015. Food and Agricultural Organisation of the United Nations, Rome. 19. 